\title{
Unfair Competition and Federal Law: Constitutional Restraints on the Scope of State Law
}

\author{
Paul Heald $\dagger$
}

Plaintiffs who bring federal claims for trademark infringement under the Lanham Trademark Act ${ }^{1}$ often assert pendent claims alleging violation of state unfair competition law. When courts determine that Lanham Act violations have occurred, they often issue injunctions that place nationwide limitations on the infringer's right to market its products. ${ }^{2}$ But even when a Lanham Act claim fails, courts nevertheless often issue similar multistate injunctions based on the pendent state law claims. ${ }^{3}$ These injunctions, in effect, subject national unfair competition suits to regulation by the laws of a single state.

This comment argues that courts should decide interstate unfair competition claims solely under federal law. More particularly, the comment argues that the multistate injunctions issued by courts on the basis of state law claims violate the commerce, due process, and full faith and credit clauses of the United States Constitution. While it may be theoretically possible to remedy the constitutional defects in these state law injunctions by crafting the injunctions more carefully, this remedy would be difficult to implement in practice. The great problems inherent in drafting constitutionally sound multistate injunctions based on state unfair competition law provide good reason for courts to consider seriously the possibility that the Lanham Act preempts state regulation of unfair competition. Exclusive application of federal law in this context would avoid the constitutional concerns that arise when courts issue multistate injunctions pursuant to a single

$\dagger$ A.B., 1980, University of Illinois; A.M., 1982; J.D. candidate, The University of Chicago, 1988.

1 The Lanham Trademark Act, 15 U.S.C. $\$ \S 1051-1127$ (1982) provides for the federal registration of trademarks. Its purpose is to protect the integrity of a trademark owner's product identity and to prevent confusion and deception of consumers. See, e.g., T \& T Mfg. Co. v. A.T. Cross Co., 587 F.2d 533, 537-38 and n.2 (1st Cir. 1978).

${ }^{2}$ See 15 U.S.C. $\$ \S 1114,1116$ (Supp. III 1985).

${ }^{3}$ See cases cited in notes 9-11. 
state's law. This comment concludes that federal law does indeed preempt state law in the field of unfair competition.

Part I of this comment explores the current situation, which finds some federal courts, particularly in the Second Circuit, issuing nationwide injunctions after deciding multistate unfair competition actions under the anomalous law of a single state. Part II explains how this practice can offend the commerce, due process, and full faith and credit clauses of the Constitution. Part III demonstrates that using ordinary remedies to address these concerns is impractical in multistate unfair competition actions. Part IV argues that courts should find that the Lanham Act preempts state unfair competition law.

\section{Multistate Injunctions Under State LaW}

Federal courts' issuance of multistate injunctions pursuant to the unfair competition laws of a single state has had two results. First, it has created disuniformity among the federal circuits: a Second Circuit court sitting in New York, for example, will frequently apply New York unfair competition law which differs from the California law that a Ninth Circuit court sitting in California would apply to the same case. ${ }^{4}$ Second, federal courts' issuance of multistate injunctions pursuant to the unfair competition laws of a single state has allowed the federal courts to extend the anomalous laws of New York and some other states to transactions utterly unrelated to those states.

This section provides three examples of areas where federal courts hearing pendent state law unfair competition claims have

- The First, Fifth, and Seventh Circuits have recognized the problem of whether to apply federal common law or state law in these cases, but they have so far avoided making explicit determinations. Instead, these courts have applied "general principles" that for all practical purposes amount to federal law. The Ninth and Second Circuits, however, always apply state law to pendent unfair competition claims. For examples of the positions of the various circuits, see Keebler Co. v. Robira Biscuit Corp., 624 F.2d 366, 371-72 (1st Cir. 1980) (applying both federal and state common law under the assumption that application of either would engender the same result); Flexitized, Inc. v. National Flexitized Corp., 335 F.2d 774, 780-81 (2d Cir. 1964); Morex S.P.A. v. Design Institute America, Inc., 779 F.2d 799, 801-02 and n.1 (2d Cir. 1985); Capital Films Corp. v. Charles Fries Productions, 628 F.2d 387, 394 n.4 (5th Cir. 1980) (followed a previous federal decision which had inferred Colorado law from federal principles and then looked to Texas law only to determine if the court's holding would be repugnant to any concepts in substantive Texas trademark law); W.T. Rogers Co., Inc. v. Keene, 778 F.2d 334, 338 (7th Cir. 1985) (refusal to determine whether federal or state common law applied because parties did not argue the question); Toho Co., Ltd. v. Sears, Roebuck \& Co., 645 F.2d 788, 792-93 (9th Cir. 1981). 
issued multistate injunctions pursuant to the anomalous unfair competition laws of individual states.

\section{A. Anti-Dilution Statutes}

Both the Lanham Act and $^{5}$ state common law ${ }^{6}$ require some element of customer confusion as to the source of a product before a claim of unfair competition can succeed. However, at least twenty states have anti-dilution statutes that prevent the "diluting" of a distinctive trademark's uniqueness even in the absence of customer confusion, by prohibiting its use on non-competing products. ${ }^{7}$ Under the dilution rationale, the owner of a distinctive mark such as "Hyatt" for hotels could prevent a law firm from using "Hyatt" as a trademark for its legal services, although there is little danger of confusion. ${ }^{8}$

The recent cases of L.L. Bean, Inc. v. Drake Pub., Inc. ${ }^{9}$ and Hyatt Corp. v. Hyatt Legal Services ${ }^{10}$ illustrate how courts sometimes use state anti-dilution statutes to enjoin nationwide commercial activity. ${ }^{11}$ In L.L. Bean, the plaintiff, a mail order catalog retailer, brought a trademark infringement action against the publisher of a national erotic magazine that had inserted a supplement called the "L.L. Beam Sex Catalog" in one of its issues. Because the plaintiff could not show a sufficient likelihood of confu-

B 15 U.S.C. § 1114(1) (1982). See R.G. Barry Corp. v. Mushroom Makers, Inc., 612 F.2d 651, 658 (2d Cir. 1979).

- See Norm Thompson Outfitters, Inc. v. General Motors Corp., 448 F.2d 1293, 1296-97 (9th Cir. 1971).

7 As of 1982, they were: Ala.Code $\S 8-12-17$ (Supp. 1982); Ark.Stat.Ann. $\S 70-550$ (1979); Cal.Bus. \& Prof.Code $\S 14330$ (West Supp. 1980); Conn.Gen.Stat.Ann. $\S 35-11$ i(c) (West 1981); Del.Code Ann. tit. 6, § 3313 (Supp. 1980); Fla.Stat.Ann. $\$ 495.151$ (West 1979); Official Code of Ga.Ann. § 10-1-451 (Michie 1982); Idaho Code § 48-512 (1977); Ill.Ann.Stat. ch. 140, \& 22 (Smith-Hurd Supp. 1982); Iowa Code Ann. § 548.11(2) (West Supp. 1982); Me.Rev.Stat. tit. 10, $\S 1530$ (1980); Mass.Ann.Laws ch. 110B, $\S 12$ (Michie/Law Coop. 1975); Mo.Ann.Stat. § 417.061 (Vernon 1979); Mont.Code Ann. § 30-13-334 (1981); Neb.Rev.Stat. § 87-122 (1981); N.M.Stat.Ann. § 57-3-10 (1981); N.Y.Gen.Bus.Law § 368-d (McKinney 1968); Or.Rev.Stat. $\$ 647.107$ (1981); R.I.Gen.Laws $§ 6-2-12$ (Supp. 1981); Tenn.Code Ann. § 47-25512 (Supp. 1982).

B See Hyatt Corp. v. Hyatt Legal Services, 736 F.2d 1153, 1157-58 (7th Cir. 1984), on remand, 618 F.Supp. 381 (N.D.Ill. 1985).

- 625 F.Supp. 1531 (D.Me. 1986), rev'd on other grounds, 811 F.2d 26 (1st Cir. 1987).

10736 F.2d 1153.

1" For other examples, see Polaroid Corporation v. Polaraid, Inc., 319 F.2d 830 (7th Cir. 1963) (injunction granted on state claims); Arthur Young, Inc. v. Arthur Young \& Co., 579 F.Supp. 384 (N.D.Ala. 1983) (plaintiffs entitled to relief under federal and Alabama laws); Estee Lauder, Inc. v. Cinnabar 2000 Haircutters, Inc., 218 U.S.P.Q. 191 (S.D.N.Y. 1982); Instrumentalist Co. v. Marine Corps League, 509 F.Supp. 323, 340 (N.D.Ill. 1981) (explicitly enjoining defendants' actions outside Illinois based on violation of Illinois law), aff'd 694 F.2d 145 (7th Cir. 1982); Pillsbury Co. v. Milky Way Productions, Inc., 215 U.S.P.Q. 124 (N.D.Ga. 1981). 
sion between the two publications, the court refused to grant summary judgment on the Lanham Act claim and a pendent claim under the Maine Deceptive Trade Practices Act. ${ }^{12}$ The court held, however, that the plaintiff was entitled to summary judgment and nationwide injunctive relief under the Maine Anti-Dilution statute. ${ }^{13}$

In Hyatt, the Hyatt Corporation hotel chain had brought a similar action against Hyatt Legal Services in federal district court in Illinois. The plaintiff sought a preliminary injunction barring Hyatt Legal Services, co-founded by Joel Hyatt, from using the name "Hyatt" without also including the name "Joel." As in L.L. Bean, because there was insufficient likelihood of confusion, only the Illinois Anti-Dilution Act claim succeeded. ${ }^{14}$ Even though $\mathrm{Hy}-$ att Legal Services' use of name "Hyatt" was perfectly permissible under federal law, and under the laws of a majority of the states, the Seventh Circuit directed the district court to enter a nationwide injunction. ${ }^{15}$

Application of such injunctions in jurisdictions that have chosen not to enact anti-dilution statutes is especially disturbing, because anti-dilution statutes undo the traditional common law right of a business to use any name that is not libelous, deceptive, or likely to confuse. ${ }^{18}$ Defendants such as Drake Publishing and Hyatt Legal Services find themselves bound nationwide by the anomalous law of a single state.

\section{B. New York Trademark Law}

The Second Circuit frequently issues injunctions pursuant to New York's anomalous unfair competition law. When determining which state law to apply to interstate unfair competition claims brought in New York, the Second Circuit in theory applies New York's conflict of laws rules. ${ }^{17}$ In practice, however, the court selects New York law without any explicit conflicts analysis or consideration of the facts of the case. ${ }^{18} \mathrm{New}$ York's unfair competition

${ }^{22}$ L.L. Bean, 625 F.Supp. at 1534-35, 1536.

13 Id. at 1536-39.

14 Hyatt, 736 F.2d at 1157-58.

${ }^{15}$ Id. at 1160.

18 The idea of dilution is a relatively recent development in this country. It was introduced into this country from German law by Frank Schecter. See Frank I. Schecter, The Rational Basis for Trademark Protection, 40 Harv.L.Rev. 813, 831-33 (1927).

${ }_{17}$ Flexitized, Inc. v. National Flexitized Corporation, 335 F.2d 774, 780-81 and n.3 (2d Cir. 1964).

18 Id; Morex S.P.A. v. Design Institute America, Inc., 779 F.2d 799, 802 n.1 (2d Cir. 
law is much broader than federal unfair competition law or other state unfair competition laws because of the "New York Rule"19 which holds that plaintiffs need not prove secondary meaning-the actual identification in consumers' minds of a trademark with a single producer ${ }^{20}$-in order to obtain protection for that trademark.

When the Second Circuit applies the New York rule to multistate unfair competition claims, it extends nationwide protection under a standard different from federal law and the law of most, if not all, states. For example, in order to win a claim for trade dress infringement under the Lanham Act, a plaintiff must prove that its product's trade dress, the packaging of a product aside from the actual trade name, has acquired secondary meaning. ${ }^{21}$ Secondary meaning is difficult to prove, especially in trade dress cases; ${ }^{22}$ by eliminating this burden, the New York rule makes unfair competition claims much more likely to succeed. Thus, plaintiffs seeking nationwide relief who bring suit on both state and federal claims in a New York district court may succeed where in other jurisdictions they might not.

Morex S.P.A. v. Design Institute America, Inc. ${ }^{23}$ illustrates the broad scope of protection provided by the Second Circuit under New York law. Design Institute America (DIA) claimed that Morex had copied its product, a shelf system for closets. ${ }^{24}$ The Sec-

1985); Perfect Fit Industries, Inc. v. Acme Quilting Co., 618 F.2d 950, 952 (2d Cir. 1980).

19 For a good, although now slightly dated, discussion of the New York Rule, see J. Thomas McCarthy, 1 Trademarks and Unfair Competition $\S \S 15: 4-5$ (2d ed. 1984).

${ }^{20}$ Under the Lanham Act, secondary meaning is not necessary to protect fanciful, arbitrary, or coined marks: e.g., Exxon, Kodak, Screaming Yellow Zonkers. However, public identification of a mark or trade dress with a specific product source is necessary to protect descriptive marks: e.g., Pizza World, or a handbag design.

${ }^{21}$ See, e.g., Brooks Shoe Mfg. Co., Inc., v. Suave Shoe Corp., 716 F.2d 854, 857 (11th Cir. 1983).

${ }^{22}$ To prove that trade dress has acquired secondary meaning, a plaintiff must show that absent any label indicating the product name, consumers recognize the product as coming from a single source. See LeSportsac, Inc. v. K mart Corp., 754 F.2d 71, 78 (2d Cir. 1985). Obviously, it is easier to prove that the shape of a Rolls Royce hood ornament has secondary meaning than to prove that a brand of toothpicks has a secondary meaning, unless they are distinctly shaped and, therefore, very well known.

${ }^{23} 779$ F.2d 799 (2d Cir. 1985), on remand, No. 84 Civ. 607, slip op. (S.D.N.Y. May 8, 1986).

${ }^{24}$ In trademark law, "copying" need not have any negative connotations. In the absence of a patent, businesses are free to copy competitors' products and a state may only intervene to prevent consumers from being misled as to the source. Sears, Roebuck \& Co. v. Stiffel Co., 376 U.S. 225, 232 (1964). Similarly, federal trademark law only prohibits the copying of those non-functional aspects of a product which have acquired secondary meaning. LeSportsac, 754 F.2d at 75 (2d Cir. 1985). See generally McCarthy, 1 Trademarks and Unfair Competition at $\S 6: 3$ (cited in note 19). 
ond Circuit found no Lanham Act violation because it concluded that DIA had failed to prove that DIA's design had acquired secondary meaning. Nevertheless, the court went on to note that New York state law does not require secondary meaning, and thus remanded for further consideration of a potential state law unfair competition claim. On remand, the determination of infringement under state law followed easily. ${ }^{25}$ As a remedy, the court issued a multistate injunction. This protection from copying in the absence of proof of secondary meaning was based solely on New York law, yet the protection afforded DIA, like other successful Second Circuit litigants, was nationwide. ${ }^{26}$

\section{Mold Statutes}

Similar problems may arise in connection with claims brought under "mold statutes."27 These recently enacted statutes prohibit the sale of products reproduced by "any direct molding process in which the original manufactured item was itself used as a plug for the making of the mold which is used to manufacture the duplicate item." ${ }^{28}$ These statutes afford protection beyond that provided by patent law, trademark laws, or the common law of unfair competition. ${ }^{29}$ It is, for example, a well-established rule at common law that manufacturers may obtain, examine, and reproduce unpatented products, a process commonly known as reverse engineering. ${ }^{30}$

To date, only one federal court has issued a nationwide injunction based partially on the violation of these mold statutes. In Metro Kane Imports, Ltd. v. Rowoco, Inc., ${ }^{31}$ a New York district

${ }^{25}$ Morex S.P.A. v. Design Institute America, Inc., No. 84 Civ. 607 (CMM), slip op. (S.D.N.Y. May 8, 1986) (available on WESTLAW).

${ }^{28}$ See also Metro Kane Imports, Ltd. v. Rowoco, Inc., 618 F. Supp. 273 (S.D.N.Y. 1985), aff'd 800 F.2d 1128 (2d Cir. 1986); Gemveto Jewelry Co. v. Jeff Cooper, Inc., 613 F.Supp. 1052 (S.D.N.Y. 1985), rev'd 800 F.2d 256 (Fed.Cir. 1986).

${ }^{27}$ Mold statutes are a new form of economic protectionism. Current states with such statutes include California, Michigan, and Tennessee. See Annot.Cal.Bus. \& Prof.Code $\S$ 17300-17301 (West 1987); Mich.Comp.Laws Annot. §§ 445.621-624 (West Supp. 1987); Tenn.Code Annot. § 47-50-111 (1984).

${ }^{28}$ Annot.Cal.Bus. \& Prof.Code $\$ 17300$ (c) (West 1987).

29 The statutes are not preempted by patent law, however, apparently because they merely eliminate one cheap method of copying and do not ban other types of copying. See Interpart Corp. v. Italia, 777 F.2d 678, 684-85 (Fed.Cir. 1985).

${ }^{30}$ See, e.g., John Wright, Inc. v. Casper Corp. 419 F.Supp. 292, 313, 316 (E.D.Pa. 1976), aff'd in part and rev'd in part, Donsco, Inc. v. Casper Corp., 587 F.2d 602 (3rd Cir. 1978). The idea that molding can be proscribed is a recent response to competition from the Far East.

${ }^{32} 618$ F. Supp. 273, 277-78 (S.D.N.Y. 1985). 
court issued an injunction prohibiting the defendant from importing its product into the United States. It did so on the grounds that the defendant's product violated New York unfair competition law and the California, Michigan, and Tennessee mold statutes. Consequently, the plaintiff received nationwide protection due to the anomalous laws of a few states.

\section{Constitutional Defects of Multistate Injunctions}

Most courts issuing nationwide injunctions pursuant to pendent state law unfair competition claims do so without explaining why the injunction, based entirely on state law, should extend beyond the borders of the state providing the law of decision..$^{32}$ In a few cases, however, courts have provided explanations for issuing multistate injunctions after finding a violation of an individual state's unfair competition law. These explanations take either of two forms. Courts may justify multistate injunctions based on explicit and implicit authorization from state unfair competition law. ${ }^{33}$ Alternatively, courts may apply an individual state's unfair competition law beyond the boundaries of that state on the argument that the state's conflict of laws principles authorize application of the state unfair competition law to the entire dispute. ${ }^{34}$

The two possible justifications for the injunctions, as well as the particular constitutional problems related to each justification, may be illustrated by a paradigm case that embodies the salient features of the application of anti-dilution statutes, mold statutes, and New York common law of unfair competition. Although this paradigm case involves a statutory regulation, it need not; identical problems would arise if anomalous state common law were involved. California has a law forbidding the common business practice of using "loss leaders," goods priced below cost in an effort to attract customers. ${ }^{36}$ In most states, this practice is perfectly legal. Suppose that a national department store chain begins a nationwide campaign to attract customers to its stores by selling a huggable teddy bear at well below its wholesale cost. It conducts this promotion in every state. Another retailer, which sells a similiar bear, brings suit in a federal court in California for trademark infringement under the Lanham Act. In addition, the retailer presses

${ }^{32}$ See, e.g., Morex, S.P.A., 779 F.2d 799; Hyatt, 736 F.2d 1153; Polaroid, 319 F.2d 830.

${ }^{33}$ See Hyatt, 610 F.Supp. 381, 385-6 (court issued injunction but stayed as to advertisements not expected to reach Illinois).

${ }^{34}$ See, e.g., Instrumentalist, 509 F.Supp. at 340.

${ }^{3 s}$ See Annot.Cal.Bus. \& Prof.Code § 17044 (West 1987). 
a state claim for loss-leading under the California statute. Neither retailer is a California resident. The court finds the bears dissimilar and therefore denies relief under the Lanham Act, but, pursuant to the California loss-leading statute, the court enjoins the first retailer from selling its teddy bears anywhere in the country.

The California federal court might support its broad injunction by either of two different lines of reasoning. First, the court might regard multistate injunctions as essential to the substantive purposes of the California law. The judges might reach this conclusion by interpreting the law either to aim directly at regulation of out-of-state competition as well as in-state competition, or to create a right within California that is susceptible of protection only by a nationwide injunction. For example, the judges might interpret the California law as seeking to ensure vigorous competition within the state of California. The judges might then construe the law to require a multistate injunction on the ground that a corporation which is unable to compete effectively outside California will be hindered in its efforts to compete effectively inside California. Regardless of whether the substantive California state law right at stake is statutory or common law in character, if the state law expressly or by construction requires regulation of commerce outside the state, evident commerce clause problems arise.

On the other hand, the California federal court might regard our paradigm case as presenting an array of related disputes centered in different states, or a single dispute not centered in California or any other single state. The laws of several states might appear relevant to all or part of the law suit. The federal court's decision to issue a nationwide injunction based on California law would then depend upon a conflict of laws analysis holding that California law governs the entire law suit. If the nationwide injunction rests on such an argument, the analysis might violate the constitutional restrictions on conflict of laws rules imposed by the due process and full faith and credit clauses.

The two different lines of justification for the multistate injunction are thus distinguishable in three respects: (1) the first justification depends on a broad construction of the underlying $s u b$ stantive rule, while the second depends on the construction of conflict of laws rules; (2) the first justification raises the question of whether any state (rather than the federal government) may regulate unfair competition in the way California has attempted to do, while the second justification raises the question of whether the law of some other state is a more appropriate rule of decision; and (3) the first justification therefore raises potential commerce clause 
problems, while the second raises potential due process and full faith and credit clause problems. Of course, it would be a mistake to regard the two lines of justification as entirely distinct. For example, a broad construction of the purposes of the underlying California substantive law might skew a conflict of laws interest analysis in favor of the application of the California law.

Only two cases have discussed the constitutional problems arising from multistate injunctions predicated upon either of the two justifications just discussed. In Instrumentalist Co. v. Marine Corps League ${ }^{36}$ the defendants claimed that under conventional principles of conflict of laws, the court could enjoin their activity only in Illinois. In rejecting the possibility of any constitutional defect in the scope of the injunction, Judge Shadur stated:

Instrumentalist has asserted a protectable Illinois property right and now seeks to enjoin conduct in Illinois and elsewhere affecting its value. It would be the height of absurdity to hold that Illinois had a legitimate interest in protecting vested rights . . . against dilution but that, having acquired jurisdiction over an offender, courts sitting in Illinois would be helpless to deal with dilutive acts once they crossed state lines. ${ }^{37}$

Judge Shadur's argument simply ignores the commerce clause restrictions on Illinois' power to create rights that depend upon the regulation of commerce outside Illinois.

Judge Moran called attention to this problem in Hyatt Corp $v$. Hyatt Legal Services ${ }^{38}$ where he criticized Judge Shadur's reasoning in Instrumentalist. According to Judge Moran, while courts certainly have the power to issue such injunctions by virtue of their jurisdiction over the parties, that fact does not resolve the issue of whether the exercise of such power has constitutional ramifications. After lengthy analysis, Judge Moran concluded that there was a strong possibility of a constitutional infirmity in the nationwide injunction. ${ }^{30}$ The remainder of this section argues that neither the substantive law justification nor the conflict of laws

36 509 F.Supp. 323 (N.D.Ill. 1983).

37 Id. at 340 .

38 610 F.Supp. 381, 382-3 (N.D.Ill. 1985).

39 Id. at 385. Judge Moran, however, was compelled by the Seventh Circuit's instructions on remand to enter a nationwide injunction anyway. Judge Moran also felt bound by the many prior Illinois precedents that had allowed issuance of a nationwide injunction in similar cases although the Illinois anti-dilution statute did not specify the scope of the injunction. Id. at $385-86$. 
justification provides courts with a constitutional basis for the issuance of multistate injunctions. Subsection A demonstrates that the commerce clause limits a court's ability to apply an individual state's unfair competition law beyond the state's boundaries. Subsection B shows that when under a conflict of laws analysis, courts must recognize that the due process and full faith and credit clauses limit the court's ability to apply the unfair competition law of an individual state beyond that state's boundaries.

\section{A. Commerce Clause Concerns}

Courts have long recognized that the commerce clause ${ }^{40}$ places implicit limits on the powers of the states to regulate interstate commerce. ${ }^{41}$ There are two basic principles of commerce clause jurisprudence: (1) that states cannot directly regulate interstate commerce; and (2) that incidental regulations of interstate commerce cannot be excessive in light of local interests. ${ }^{42}$

Two recent Supreme Court decisions indicate that an extraterritorial application of state unfair competition law, like that described in our paradigm case, would be unconstitutional under this two-pronged commerce clause analysis. In Brown-Foreman Distillers v. N.Y. Liquor Authority, ${ }^{43}$ the Supreme Court used the first of the two principles-that no state statute may directly regulate interstate commerce-to strike down a New York law. The law in question required distillers doing business in the state to sell liquor to New York wholesalers at a price no higher than the lowest price given to wholesalers in other states. In effect, the law prevented a distiller from reducing her prices in other states once the distiller had posted her prices in New York unless the New York Liquor Authority approved the price reduction. Justice Marshall wrote that the law effectively "forc[ed] a merchant to seek regulatory approval in one state before undertaking a transaction in another"44 and held the law unconstitutional as a direct regulation of commerce. ${ }^{45}$ Applying Brown to the paradigm case, a reviewing court would have to hold the district court's issuance of a multistate injunction unconstitutional: by applying the California law beyond California's borders, the district court allowed California to regu-

40 U.S. Const. art. I, \& 8, cl. 3.

11 See Cooley v. Board of Wardens, 53 U.S. 299, 318-19 (1851).

${ }^{42}$ See Brown-Forman Distillers v. N.Y. Liquor Authority, 476 U.S. 573, -, 106 S.Ct. 2080, 2084 (1986); Edgar v. MITE Corp., 457 U.S. 624, 640 (1982).

43476 U.S. 573, 106 S.Ct. 2080 (1986).

44 Brown-Forman, 476 U.S. at -—, 106 S.Ct. at 2086.

15 Id., 476 U.S. at --, 106 S.Ct. at 2087. 
late commerce outside its borders. California, by virtue of the court's order, could proscribe loss-leading schemes in Nevada, for example. The Court's opinion in Edgar v. $M I T E^{46}$ illustrates how the court's order in the paradigm case might offend the second commerce clause principle mentioned above, the idea that incidental regulations violate the commerce clause if excessive in light of local interests. In Mite, the Court held that the Illinois Business Takeover Act ${ }^{47}$ violated the commerce clause. The Illinois statute required any person attempting to take over a "target" corporation to notify the Secretary of State of Illinois and to file certain papers. The statute defined a target company as any corporation with ten percent of its shares held by Illinois residents or any company that met two of the following three criteria: (1) had its principle place of business in Illinois, (2) was organized under Illinois law, or (3) had at least ten percent of its capital in Illinois. ${ }^{48}$ Because of this broad definition of a target company, the statute applied to a wide range of takeover offers, including those made by out-of-state offerors to out-of-state offerees. For example, in Mite itself, as Justice White noted, only 27 percent of the target company's shareholders resided in Illinois, ${ }^{40}$ yet the statute's broad terms allowed regulation. Justice White also pointed out that the principal office and capital requirements of the Illinois statute effectively allowed Illinois to regulate transactions where not one shareholder resided in Illinois. ${ }^{50}$

The Court held that even if the Illinois statute only regulated interstate commerce indirectly, it still violated the commerce clause because "the Act imposes a substantial burden on interstate commerce which outweighs its putative local benefits." $M I T E$, then, the district court's order in the paradigm case would offend the commerce clause even if the reviewing court found that the California law, as applied by the court, did not directly regulate interstate commerce. The multistate injunction in the paradigm case imposes a substantial burden on interstate commerce it prohibits the national department store from selling one of its products in any state. Further, California's interest in the issuance

18457 U.S. 624 (1982).

${ }^{77}$ Ill.Rev.Stat. ch. 121 1/2, II 137.51-137.70 (1981), repealed by Act of Sept. 14, 1983, 1983 Ill.Laws 3094 .

48 Ill.Rev.Stat. ch. 1211/2, I 137.52-10 (1981).

48457 U.S. at 642 (plurality opinion).

so Id.

s1 457 U.S. at 646 . The court specifically ruled that the state had no interest in protecting out-of-state shareholders. Id. at 644 . 
of the injunction does not outweigh this burden because (1) California's interest in protecting its consumers cannot extend beyond the state's boundaries and (2) California does not have a legitimate interest in regulating non-resident companies' business outside of California. It is important to keep in mind here that the California loss-leading statute is not unconstitutional if applied solely within California's borders. Only the court's application of the statute to impose an injunction reaching beyond the state's boundaries offends the commerce clause. ${ }^{.2}$

One lower court opinion, discussed briefly earlier in this comment, ${ }^{53}$ recognized that otherwise valid state unfair competition laws can offend the commerce clause if applied beyond the state's borders. In Hyatt Corp. v. Hyatt Legal Services, the district court believed that the Illinois anti-dilution statute could be applied validly within the state of Illinois, but could not be the basis for an injunction constraining business activity outside the state, except in the case of advertisements reasonably expected to reach Illinois. ${ }^{54}$ However, because the Seventh Circuit had remanded to the district court for the entering of a nationwide injunction, ${ }^{55}$ the district court was compelled to issue the injunction.

The district court in Hyatt felt that the issuance of a nationwide injunction pursuant to the Illinois Anti-Dilution Act would violate the commerce clause for many of the same reasons that the laws in Brown-Forman and MITE did. First, the court stated that the injunction appeared to be a direct interference with interstate commerce because it enjoined the defendant's activity in states where that activity was perfectly legal. ${ }^{56}$ Second, the district court believed that even if the statute only indirectly regulated interstate commerce, it still violated the commerce clause because the local interest asserted-protection of a corporation's trademark in Illinois-did not outweigh the extreme burden placed on interstate

B2 For a related discussion, see Justice White's treatment of blue sky laws in MITE, 457 U.S. at 64I-2. He cites the several Supreme Court opinions holding that state laws regulating tender offers within a state are constitutional. If the Illinois statute had functioned as a blue sky law by regulating only intrastate transactions, it would not have violated the commerce clause. However, the Court found that "[t]he Illinois Act differs substantially from state blue-sky laws in that it directly regulates transactions which take place across state lines, even if wholly outside Illinois." The extraterritorial effect of the law made it unconstitutional in application.

${ }^{83}$ See notes 38-39 and accompanying text.

s4 Hyatt, 610 F. Supp. at 385 .

ss 736 F.2d. at 1160 .

se 610 F.Supp. at 383-84. 
commerce. ${ }^{57}$

The district court in Hyatt is, notably, the only court that has thoroughly addressed the commerce clause problems that arise in these nationwide injunction cases. As the Hyatt court recognized, multistate injunctions issued under state law directly regulate interstate commerce if the injunction proscribes purely out-of-state commerce. These injunctions are particularly objectionable when they are issued pursuant to an anomalous state law that forbids practices that other states accept or even encourage. Moreover, even if one were to dispute that these injunctions are direct regulations of interstate commerce, it seems apparent that the local interest (basically, an interest that is only a state property right) does not justify infringing upon commerce in numerous other states.

\section{B. Due Process and Full Faith and Credit Concerns}

The due process and full faith and credit clauses also limit the extent to which federal courts may apply the unfair competition laws of an individual state beyond the state's boundaries. These limitations are important when the courts apply the laws of a single state to restrain conduct occurring partly or entirely within other states where such conduct is either permitted or encouraged. In order to apply the law of the forum state to such out-of-state activity, the court must undertake a choice of laws analysis.

The Supreme Court has recently said that the due process clause and the full faith and credit clause impose identical restrictions on the Court's choice of law analysis and therefore need not be considered separately. In Allstate Ins. Co. v. Hague, ${ }^{68}$ the plurality described the test to be applied under either clause:

[The] Court has traditionally examined the contacts of the State, whose law was applied, with the parties and with the occurrence or transaction giving rise to the litigation .... In order to ensure that the choice of law is neither arbitrary nor fundamentally unfair ... the Court has invalidated the choice of law of a State which has had no significant contact or significant aggregation of contacts, creating state interests, with the parties and the occurrence or transaction. ${ }^{59}$

57 Id. at 384.

s8 449 U.S. 302 (1981).

s9 Id. at 308 (plurality opinion)(emphasis added and citations omitted). See also id. at 308 n.10 and 332 (Powell dissenting); Phillips Petroleum Co. v. Shutts, 472 U.S. 797, 818-19 
Under this test, before a state can constitutionally apply its law to a controversy, it must have a significant interest in the controversy and there must be significant contacts with the state. In addition, the Supreme Court has indicated that the due process and full faith and credit clauses require courts to consider the expectations of the parties and decide whether application of the state law to the dispute would surprise the parties so much that it would be arbitrary or fundamentally unfair. ${ }^{60} \mathrm{~A}$ recent Supreme Court decision illustrating this test provides an excellent analogy to the unfair competition problem. The Supreme Court in Phillips Petroleum Co. $v$. Shutts ${ }^{61}$ held that a court violates the full faith and credit and due process clauses by applying a single state's laws to a class action when a significant number of the claims and claimants have no contact with the state. In Shutts, 28,000 plaintiffs brought a class action in a Kansas state court against Phillips Petroleum Company to recover interest on their suspended oil and gas royalties. The plaintiffs were residents of all fifty states and of several foreign countries. Most of the oil and gas wells in question were in Texas, Oklahoma, and Louisiana, with fewer than 5 percent in Kansas. Phillips was incorporated in Delaware with its principal place of business in Oklahoma. In spite of Kansas' minimal association with most of the claims involved in the action, the Kansas Supreme Court applied Kansas law because "the law of the forum should be applied unless compelling reasons exist for applying a different law." ${ }^{2}$ Reversing this decision, the United States Supreme Court held that the application of Kansas law violated the due process and full faith and credit clauses:

Kansas must have a "significant contact or significant aggregation of contacts" to the claims asserted by each member of the plaintiff class, contacts "creating state interests," in order to ensure that the choice of Kansas law is not arbitrary or unfair . . . . Given Kansas' lack of "interest" in claims unre-

(1985) (one test applied for both clauses). Over the years, there has been disagreement with the Court's use of a single test. In his concurring opinion in Allstate, Justice Stevens implied that a state's choice of law may violate one clause without violating the other, since they address different concerns. 449 U.S. at 320 . This comment will analyze the constitutional concerns under the traditional test. For a recent discussion of the effect that should be given to the full faith and credit clause, see Arthur R. Miller and David Crump, Jurisdiction and Choice of Law in Multistate Class Actions After Phillips Petroleum Co. v. Shutts, 96 Yale L.J. 1 (1986).

so Shutts, 472 U.S. at 822.

81 472 U.S. 797 (1985).

${ }^{62}$ Shutts v. Phillips Petroleum Co., 235 Kan. 195, 221, 679 P.2d 1159, 1181 (1984). 
lated to that State, and the substantive conflict with jurisdictions such as Texas, we conclude that application of Kansas law to every claim in this case is sufficiently arbitrary and unfair as to exceed constitutional limits. ${ }^{63}$

Like the lower court in Shutts applying Kansas law to claims unrelated to the state, courts issuing nationwide injunctions pursuant to state unfair competition claims frequently bar transactions largely unrelated to the interests of the forum state. The lack of "significant contact or aggregation of contacts" with enjoined transactions in other states casts doubt on many unfair competition decisions that apply forum law to multistate actions. Much depends on the particular facts of the case, such as the residence of the parties, the purpose of the law, and the place where the tort occurred. For example, the paradigm involving the nationwide application of the California loss-leader statute is a dispute between two parties who are not residents of California. California would find it nearly impossible to justify the application of its own law in the other forty-nine states, given that neither business is a resident, and given that California has no legitimate interest in protecting non-resident consumers. ${ }^{84}$

The case is closer if the plaintiff were a California resident. A resident plaintiff could argue that all the damage it suffers nationwide comes to rest at its principal place of business, in this case California. California, of course, has a legitimate interest in protecting resident businesses.

Even the legitimacy of this interest will depend on other factors. If the statute had been enacted to protect consumers rather than local businesses, the mere fact that the plaintiff was a business resident would not constitute an interest sufficient to satisfy the due process or full faith and credit clauses. Thus, perhaps a state unfair competition law designed to protect consumers could never be applied beyond a state's borders because the state would never have a legitimate interest in protecting non-resident consumers.

Most state unfair competition laws, however, are not designed to further consumer interests. The laws considered in this comment - anti-dilution statutes, mold statutes, and New York common law - tend to favor established businesses at the expense of

${ }^{83}$ Shutts, 472 U.S. at $821-22$ (citation omitted).

ot See id. at 822 (noting "Kansas' lack of 'interest' in claims unrelated to that State"); MITE, 457 U.S. at 644 (no interest for commerce clause purposes). 
would-be competitors. ${ }^{65}$ Because the purpose of these statutes is to protect established businesses, a resident plaintiff has a stronger argument that the application of forum law to activity outside of the forum furthers this state interest and is therefore constitutional. Unfortunately, the legitimacy of a state's interest in the extra-territorial application of its unfair competition laws is not explored in published opinions.

As mentioned earlier, in addition to analyzing the state's interest in these cases, courts must consider the reasonable expectations of the parties to the lawsuit before concluding that the issuance of multistate injunctions pursuant to a single state's unfair competition law does not violate the full faith and credit or due process clauses. Accompanying the issuance of broad multistate injunctions, there is a strong element of unfair surprise. The California loss-leader paradigm provides an example. In a case involving two non-resident parties, the court could not reasonably conclude that either side expected that an anomalous California law would govern the defendant on a national scale. When the property right at stake is locally created and neither party is locally based, an element of unfair surprise will likely always exist. This is especially true where most other states do not even recognize such a property interest, as is the case with the California loss-leader statute and with the anti-dilution and mold statutes.

Even if the plaintiff business were a resident of California, there would still be an element of unfair surprise when a court issued a nationwide injunction pursuant to state law. It is one thing to be enjoined only in California; that may be a risk that the defendant accepts when competing with California businesses. However, the defendant can hardly foresee a nationwide injunction based solely on California's anomalous state law. As mentioned above, the state may nevertheless have a strong interest that outweighs this fairness concern.

There can be no definitive answer as to whether or not multistate injunctions in unfair competition cases violate the full faith and credit and due process clauses. These cases exhibit endless difficult variations in the number and residency of the parties, the number and location of the tort(s), the purposes of the state law,

os See, e.g., Estee Lauder, Inc. v. Cinnabar 2000 Haircutters, Inc., 218 U.S.P.Q. 191, 192 (S.D.N.Y. 1982)("The aim of [New York's anti-dilution statute] . . . was not to 'remedy . . . public confusion caused by similar products,' but rather to remedy 'a cancer-like growth of dissimilar products or services which feeds upon the business reputation of an established distinctive trade-mark or name." "). 
and the legitimacy of the state interest. Shutts, however, establishes that neither state nor federal courts can automatically apply forum law in multistate unfair competition cases. Courts in these cases must be more mindful of constitutional restrictions when choosing to apply forum law.

\section{IMPRACTICALITY OF TRADITIONAL REMEDIES in Unfair Competition Cases}

The serious constitutional defects inherent in giving extra-territorial effect to state unfair competition laws might be solved, at least in theory, by more restrictive injunctions that satisfy the commerce, full faith and credit, and due process clauses. This section argues, however, that federal courts will find it extremely difficult to limit injunctions when finding for a plaintiff on a pendent state unfair competition claim.

\section{A. Impracticality of Issuing Limited Injunctions that Satisfy the Commerce Clause}

By limiting the scope of an injunction to the state under whose unfair competition law it was issued, a court would be less likely to violate the commerce clause. Statewide injunctions would protect the local interest while avoiding direct regulation of interstate commerce. While statewide injunctions might still burden interstate commerce, such regulation would be incidental at most.

Unlike the situation in $M I T E{ }^{68}$ moreover, the local interests in unfair competition cases would likely justify any incidental burden on interstate commerce. In MITE, the appellant argued that the statute was enacted in part to protect shareholders and in part to regulate the internal affairs of Illinois corporations. However, since so few shareholders actually resided in the state, the Court found that there was an insufficient local interest to justify the statute. Similarly, the Court felt that the state could have no administrative interest in regulating transactions between out-ofstate offerors and out-of-state offerees. In contrast with the extraterritorial application of the Illinois law in MITE, statewide unfair competition injunctions serve truly local interests. These injunctions would protect any local property rights and would place less

66457 U.S. at 643-46. In Brown-Forman, the Court did not consider whether the New York liquor law violated the second tier of its analysis, since it had already determined that the statute directly regulated interstate commerce. Brown-Forman, 476 U.S. at --, 106 S.Ct. at 2086. 
of a burden on interstate commerce than the law challenged in MITE. These injunctions, therefore, would not offend the commerce clause in most unfair competition cases.

However, while single state remedies would usually satisfy the commerce clause, they are a burdensome alternative to the nationwide injunction. Such a procedure might force a plaintiff to bring suits in all fifty states in an attempt to vindicate his common law rights in all jurisdictions. This is especially true when the right in question cannot be neatly characterized as "anomalous" and clearly actionable only under the law of a single state, for example, New York. ${ }^{67}$ Thus, a state-by-state system, while a constitutional alternative to the nationwide injunction, would be extremely burdensome on both the courts and the parties who would have to engage in such litigation.

\section{B. Impracticality of a Constitutionally Sound Choice of Laws Analysis}

One might argue that courts can avoid the full faith and credit and due process problems noted earlier if courts only applied state unfair competition laws beyond the state boundaries if the Shutts significant contacts standard were satisfied and if application of the state law would not unreasonably surprise the parties. At first glance, this solution seems straightforward. Courts are not sensitive enough to the constitutional dimensions of their choice of law decisions, and, therefore, a more careful examination of constitutional constraints on choice of law would result in much less objectionable unfair competition decisions.

For example, a return to the strict territorialist approach, the principle that the law to be applied is the law of the state where the tort occurred, ${ }^{68}$ would certainly result in a constitutional, albeit awkward regime. If an activity occurring in all fifty states was adjudicated on a state-by-state basis with no state law being given extra-territorial effect, then none of the full faith and credit and due process concerns would be raised.

Such an imaginary regime would be a nightmare to adminis-

${ }^{67}$ For example, in Carson v. Here's Johnny Portable Toilets, 810 F.2d 104 (6th Cir. 1987), the court was faced with the prospect of trying to decide whether a particular state would recognize a "publicity right" or not. Many states lack any law on the matter and plaintiff in such a case would literally have to go to almost every state to have his rights determined.

${ }^{\text {68 }}$ See, e.g., American Law Institute, Restatement of Conflict of Laws $\$$ 377-390 (1934). 
ter. ${ }^{69}$ Applying fifty laws to fifty fact situations would involve the courts in an enormous task. In addressing the similar difficulties in adjudicating class actions on a piecemeal basis, Professors Arthur Miller and David Crump observed:

Beyond the difficult task of correctly determining foreign law, the nationwide class action may present an even greater problem because of the sheer burden of organizing and following fifty or more different bodies of complex substantive principles. . . . [One] way to appreciate the dimension of the task is to consider that fifty opinions are more than most appellate judges write in a year. The fifty-state-plus-foreign-countries class action may create a comparable workload within the confines of a single class. ${ }^{70}$

Such an approach is not likely to appeal to any modern court. In any event, very few states still adhere to a per se rule that the place of the tort determines the law of the case. ${ }^{71}$ The question arises, then, as to what choice of law principle can effectively address the constitutional concerns mentioned above. In order to satisfy the due process and full faith and credit clauses, the choice-oflaw in the multistate unfair competition case must be sensitive to possible conflict of laws in every relevant jurisdiction. Where such conflicts exist, the court cannot apply a single state's law without assessing the state's "contacts or aggregation of contacts" with the parties before it, and with all of the activities in-state and out-ofstate that the plaintiff is seeking to enjoin. In addition, the reasonable expectations of the parties must be considered to ensure that the choice is neither arbitrary nor unfair. Thus a court must consider the laws and policies of as many as fifty states, and the court must evaluate a state's interest in regulating all of the proscribed activities wherever they are to be enjoined. Although many modern conflicts rules take into account constitutional considerations and simplify courts' decisions when considering choice of law issues, these rules would not prove practical in unfair competition cases.

69 The Sixth Circuit, however, has expressed a willingness to try. In Carson, the court refused to limit the geographical scope of nationwide injunction issued under Michigan's common law right to publicity. $810 \mathrm{~F} .2 \mathrm{~d}$ at 105,106 . However, it explicitly withheld jurisdiction over the case in order to allow the defendant at a later date to argue that its expansion of business into a state outside Michigan would not violate the internal substantive law of that state. Therefore, under the Sixth Circuit's analysis, the defendant who wishes to operate nationwide is forced to argue the law of the other forty-nine states in order to modify the injunction.

70 Miller and Crump, 96 Yale L.J. at 64 (cited in note 59).

${ }^{11}$ American Law Institute, Restatement of Conflict of Laws 2d $\S 6$ and 145 (1971). 
Sections 6 and 145 of the Second Restatement, ${ }^{72}$ for example, suggest that courts should apply the law of the state having the "most significant relationship" to the transactions and the parties in question. To take another example, the "interest analysis" approach developed by Professor Brainerd Currie ${ }^{73}$ examines the underlying policies of the states involved in an effort to determine when application of ones state's law implicates real policy conflicts. Robert Leflar's "better law"74 approach relies on five main considerations: (1) predictability of outcome, (2) maintenance of interstate and international order, (3) simplification of the judicial task, (4) advancement of the forum state's governmental interests, and (5) application of the better rule of law. Under any of these approaches, a court attempting to assure a constitutional choice of law may face an overwhelming task, even if the end result is the application of one state's law.

What would a proper attempt to apply these conflicts rules look like in the multistate unfair competition situation? The following paradigm is offered, not to restate the point that applying ordinary conflicts rules is impractical, but to illustrate the problems that arise when modern marketing techniques and a multistate corporation are involved in a typical unfair competition claim.

McDonald's and its franchises operate and advertise in various media in all fifty states. Burger King and its franchises also operate and advertise in all fifty states. Neither is a resident of New York. Suppose that McDonald's starts to market and advertise a new sandwich, the "Hamboni," which is identical to Burger King's enormously popular sandwich, the "Hamcheesie." Burger King files suit in federal district court in the Southern District of New York bringing a Lanham Act claim and a common law unfair competition claim. Because Burger King cannot prove a likelihood of customer confusion, the Lanham Act claim fails. How should the court approach the choice of law issue regarding the state law claim?

The federal court must try to apply New York conflicts rules, ${ }^{75}$ but the court must also ensure that application of the New York

72 Id.

${ }^{73}$ See Brainerd Currie, Married Women's Contracts: A Study in Conflict-of-Laws Method, 25 U.Chi.L.Rev. 227 (1958).

" See Robert A. Leflar, Choice-Influencing Considerations in Conflicts Law, 41 N.Y.U.L.Rev. 267, 282 (1966).

${ }^{78}$ See Klaxon v. Stentor, 313 U.S. 487, 496 (1941) (federal courts must apply the forum state's choice of law rules). 
unfair competition law does not violate the due process or full faith and credit clauses. Under Shutts, the court will therefore have to determine whether New York has "significant contacts" with the dispute between Burger King and McDonald's to justify the nationwide injunction. The court will also have to guarantee that McDonald's and Burger King will not be unfairly surprised by nationwide application of the New York law. Resolution of these questions will require that the court engage in complicated empirical analysis.

A look at one of the rare cases where a court was responsive to the multistate nature of an unfair competition claim reveals the complexity of an analysis involving just four states and two parties. In Ettore v. Philco Television Broadcasting Corporation, ${ }^{76}$ the Third Circuit was confronted with a situation involving the broadcast in Philadelphia and New York of an old boxing match without the boxer's consent. The court noted the complex choice of laws decision that it needed to make:

We must now look to Pennsylvania law with regard to the alleged injuries in Pennsylvania and, under the Pennsylvania conflict of laws rule, to the laws of Delaware and New Jersey as to the Pennsylvania telecasts and to the law of New York as to the New York telecasts, to determine what damage, if any, Ettore suffered in each of these jurisdictions. Moreover, since the NBC New York telecasts penetrated New Jersey, we must look also to the law of New Jersey through the double lens of Pennsylvania and New York conflict of laws rules to determine Ettore's injuries in New Jersey insofar as [the defendant] is concerned. ${ }^{77}$

Any court rule that is responsive to the constitutional concerns enunciated above thus faces a Herculean task in confronting a multistate unfair competition case. A constitutionally sound judgment can eventually be rendered, but adjudication under state law is clearly impractical and unwieldy.

Fortunately, Congress has already legislated a solution to the problem of adjudicating multistate unfair competition claims. The remainder of this comment proposes that courts should reevaluate the extent to which the Lanham Act preempts state unfair competition laws. 


\section{Federal Law and Unfair Competition}

Until recently, there was little reason to argue the extent to which the Lanham Act preempted state unfair competition law. Before Erie Railroad v. Tomkins, ${ }^{78}$ federal law controlled all unfair competition claims brought in diversity in federal court. Even after Erie, as a result of the widespread federal law in this area, courts still resorted to federal precedent. As one court noted:

[T] he states had little occasion to build an independent body of case law in these areas. For this reason and because of the multistate nature of the problem, instead of formulating novel concepts many present day courts after paying homage to Erie resort to the well defined federal doctrines. ${ }^{79}$

However, the recent rise of anti-dilution and mold statutes raises the question of preemption in earnest. This section will first argue that the Lanham Act preempts state unfair competition laws. Second, it will demonstrate that preemption will not greatly change the substance of the law because many courts already apply federal law to multistate claims.

\section{A. Lanham Act Pre-emption}

The Supreme Court has delineated several ways to determine whether a federal enactment preempts state law. Courts should consider a federal law preemptive if "Congress has explicitly mandated the pre-emption of state law, . . . or has adequately indicated an intent to occupy the field of regulation, thereby displacing all state laws on the same subject." In absence of an express or implied congressional intent, state law will be preempted only "to the extent it actually conflicts with federal law." An actual conflict exists when " "compliance with both state and federal regulations is a physical impossibility,' ... . or when state law 'stands as an obstacle to the accomplishment and execution of the full purposes and objectives of Congress." "80

78 304 U.S. 64 (1938) (federal courts sitting in diversity must apply the law of the states and not federal common law). For discussion of the impact of Erie on unfair competition litigation, see Sergei S. Zlinkoff, Erie v. Tompkins: In Relation to the Law of Trade-Marks and Unfair Competition, 42 Colum.L.Rev. 955 (1942); Jerome Gilson, 1 Trademark Protection and Practice $\$ 7.01$ (1985); James W. Moore, Walter J. Taggart, Allan D. Vestel, and Jeremy C. Wicker, 1A Moore's Federal Practice I 0326 (1985).

${ }^{79}$ Taussig v. Wellington Fund, Inc., 187 F.Supp. 179, 193 (D.Del. 1960), aff'd 313 F.2d 472 (3d Cir. 1963).

${ }^{80}$ Brown v. Hotel Employees, 468 U.S. 491, 501 (1984). See also Louisiana Public Service Comm'n v. F.C.C., 476 U.S. 355, -—, 106 S.Ct. 1890, 1898 (1986). 
Applying this test in the present context, the first line of inquiry is whether Congress expressly or impliedly intended to preempt state unfair competition law when it passed the Lanham Act. If the answer to this question is no, then one must ask whether state law "actually conflicts" with federal law and is thus preempted. Each of these points will be considered in turn.

1. Intent of Congress. Nothing in the Lanham Act expressly states that it was intended to preempt all state regulation of unfair competition. Indeed, as one commentator has noted, "the Act expressly recognizes the legitimacy of state regulation in some instances." the Lanham Act.

Two important sections of the Lanham Act arguably point to preemption of state unfair competition law. Section 45 states that "[t]he intent of this [Act] is to regulate commerce within the control of Congress. ... . [and] to protect persons engaged in such commerce from unfair competition."82 And, § 44(h) states that "[a]ny person designated in paragraph (b) of this section [foreign nationals] . . . shall be entitled to effective protection against unfair competition, and the remedies provided in this [Act] for infringement of marks shall be available so far as they may be appropriate in repressing acts of unfair competition." terms $\S 44(\mathrm{~h})$ only applies to foreigners, $\S 44(\mathrm{i})$ states that U.S. citizens shall have the same benefits as others under $\S 44,{ }^{84}$ which would include a federal cause of action for unfair competition under $\S 44(\mathrm{~h})$.

Section $44(\mathrm{~h})$ thus seems to a good indicator of Congress' intent to codify the broad range of federal regulation of unfair competition that existed before Erie. Other authorities also provide support for this view. Justice White has noted that "the purpose of the Lanham Act was to codify and unify the common law of unfair competition and trademark protection." ${ }^{85}$ Professor McCarthy remarks that:

The drafters and promoters of the 1947 Lanham Act . . . strongly felt that the Act should create a general federal law

s1 Milton W. Handler, Are the State Antidilution Laws Compatible with the National Protection of Trademarks?, 75 Trade-Mark Rptr. 269, 283 (1985) (referring to 15 U.S.C. $\S$ 1065).

s2 15 U.S.C. § 1127 (1982).

8s 15 U.S.C. $\S 1126(\mathrm{~h})(1982)$.

s4 15 U.S.C. $\$ 1126(\mathrm{i})$ (1982).

${ }^{85}$ See Inwood Laboratories v. Ives Laboratories, 456 U.S. 844, 861 n.2. (1982) (White concurring). 
of unfair competition. This was in part a reaction to the 1938 Erie Railroad Supreme Court decision, which, it was felt, had eliminated the existing body of federal unfair competition common law. ${ }^{88}$

Many other commentators who have studied the Congressional hearings and legislative history agree that Congress intended that federal law alone would regulate trademarks used in interstate commerce. ${ }^{87}$ As one commentator has pointed out, " $\left.t\right]$ he legislative history of the Lanham Act clearly indicates that uniformity of trademark law . . . was one of the primary objectives of the Lanham Act." 88 To achieve uniformity, federal regulation is almost essential; thus, one can conclude that Congress must have intended to codify the law of unfair competition and preempt state law.

Opponents of preemption argue that $\S 43(\mathrm{a})$ is the most important enunciation of the Act's scope. That section creates a federal cause of action for false descriptions or representations of goods. ${ }^{89}$ Proponents of state unfair competition law argue that

${ }^{86}$ McCarthy, 1 Trademarks and Unfair Competition at 341 (cited in note 19).

${ }^{87}$ See especially Handler, 75 Trade-Mark Rptr. at 285 (cited in note 81); Gilson, 1 Trademark Protection and Practice at $\$ 7.01$ (2) (cited in note 78) (arguing that Congress dismantled the patchwork structure of Erie by establishing a nationally uniform law governing the trademark infringement aspects of unfair competition); Joseph P. Bauer, A Federal Law of Unfair Competition, 31 U.C.L.A.L.Rev. 671, 679-81 (1984) (Congress intended to create a uniform federal law of unfair competition); Walter J. Derenberg, Federal Unfair Competition Law at the End of the First Decade of the Lanham Act, 32 N.Y.U.L.Rev. 1029, 1029-39 (1957) (Act was intended to avoid the consequences of Erie by creating a private federal law of unfair competition with respect to the sale of good or services); Julius $R$. Lunsford, Trade-Marks and Unfair Competition-The Demise of Erie v. Tompkins?, 40 Trade-Mark Rptr. 169, 179 (1950) (commentators interpret the Lanham Act to mean that the Erie doctrine no longer applies to unfair competition); Charles Bunn, The National Law of Unfair Competition, 62 Harv.L.Rev. 987, 998-1001 (1949) (either the Federal Trade Commission Act or the Lanham Act preempts state law in cases involving interstate commerce); Daphne Robert, The New Trade-Mark Manual 170-186 (1947) (the Lanham Act, its legislative history, and our international conventions make it evident that the Act reestablished a federal code of unfair competition, independent of registration under the Act).

s8 Handler, 75 Trade-Mark Rptr. at 285 (cited in note 81). To support his reasoning, Handler cites to a Senate committee report that stated:

[T]rade is no longer local, but is national. Marks used in interstate commerce are properly the subject of Federal regulation. It would seem as if national legislation along national lines securing to the owners of trade-marks in interstate commerce definite rights should be enacted and should be enacted now.

See Sen.Rep.No. 1333, 79th Cong, 2d Sess., reprinted in 1946 U.S.Code Cong. \& Admin.News 1274, 1277 (1946).

${ }^{89}$ See 15 U.S.C. $\$ 1125$ (a) (1982):

Any person who shall affix, apply, or annex, or use in connection with any goods or services, or any container or containers for goods, a false description of origin, or any false description or representation, including words or other symbols tending falsely to describe or represent the same, and shall cause such goods or services to enter into 
Congress by creating a federal cause of action in this narrow circumstance indicated its intention to leave state law intact in the rest of the unfair competition field.

Two different statutory arguments, therefore, suggest different views about the scope of the federal law of unfair competition. Most courts ruling on this issue have held that $\S 44(\mathrm{~h})$ does not establish federal unfair competition law of broad scope. ${ }^{90}$ These courts emphasize that $\S 44(\mathrm{~h})$ appears at the end of a section dealing entirely with the rights of foreign nationals. Although they admit that $\S 44$ (i) expressly incorporates American citizens into $\S$ 44(h)'s provisions, they express doubt that Congress would indicate its intention to create a broad federal law of unfair competition in such an oblique way.

The courts' reasoning here seems strange in light of the statute's clear provisions. The reasoning also seems to ignore the stated purpose of the Lanham Act. Thus, there is little to justify those courts who have ruled against Lanham Act preemption of state law on the basis of congressional intent. However, even if the courts were correct and one could not evince from Congress a clear intent to preempt state law on this issue, certainly one can find that state law should be preempted under the "actual conflicts" portion of the preemption doctrine.

2. "Actual Conflicts" Analysis. Although it is arguable whether Congress specifically intended to preempt state law in the area of unfair competition, certainly there is a strong argument in favor of preemption because state law "stands as an obstacle to the accomplishment and execution of the full purposes and objectives of Congress." One district court has ruled that the Lanham Act preempts state law for this very reason.

In United States Jaycees $v$. Commodities Magazine Inc., ${ }^{91}$ the district court struck down the Iowa anti-dilution statute because it conflicted with the Lanham Act's objective of providing uniformity

commerce, and any person who shall with knowledge of the falsity of such designation of origin or description or representation cause or procure the same to be transported or used in commerce or deliver the same to any carrier to be transported or used, shall be liable to a civil action by any person . . . likely to be damaged by the use of any such false description or representation.

"O See Royal Lace Paper Works v. Pest-Guard Products, 240 F.2d 814, 816-820 (5th Cir. 1957); Iowa Farmers Union v. Farmer's Educational \& Coop., 247 F.2d 809, 819 (8th Cir. 1957); American Auto. Assn' v. Spiegel, 205 F.2d 771, 774-5 (2d Cir. 1953). But see discussion of former Ninth Circuit approach in Toho Co., Ltd. v. Sears, Roebuck \& Co., 645 F.2d 788, 791-92 (9th Cir. 1981).

21661 F.Supp. 1360, 1365-68 (N.D.Iowa 1987). 
in the area of unfair competition law. ${ }^{92}$ The court stated that:

In providing greater rights to holders of trademarks than are available to them under the Lanham Act, [the Iowa statute] and various other state dilution statutes frustrate "the accomplishment and execution of the full purposes and objectives of Congress" . . . by supplanting the uniform and definite rights contained in the Lanham Act, which are intended for those who trade in interstate commerce, with a checkerboard of differing rights. . . . The Iowa statute would conflict with one of the major goals of the Lanham Act - uniformity - if it were applied to goods in interstate commerce. Thus, to the extent that [the anti-dilution statute] regulates interstate commerce, it is preempted by the Lanham Act."

In addition to the uniformity concerns mentioned in Jaycees, state anti-dilution statutes and unfair competition laws frustrate other ends of the Lanham Act. A vehement objection to the Act at the time of its drafting was that it granted monopolistic rights to trademark owners. ${ }^{94}$ To limit the scope of this monopoly, the Act was drafted to protect trademark rights only if there was a likelihood of confusion as to the origin of the product. Thus, a business can enforce its rights only by showing that enforcement of those rights protects consumers. State anti-dilution statutes, however, provide for protection even in the absence of confusion, as does New York common law, which provides protection from mere copying. Any state unfair competition law which grants monopolistic trademark rights without a confusion rationale actively frustrates the goals of the Lanham Act. The Act strikes a delicate balance in order to further the public interest, and any state law which upsets this balance should be preempted.

\section{B. Federal Common Law of Unfair Competition}

One sees from the preceding discussion that there are strong arguments for preemption. Many, however, still oppose the idea that the Lanham Act preempts state unfair competition law. These

${ }^{82}$ See note 87 and accompanying text. Such a holding was perhaps inevitable given the increasing reach of federal power under the Lanham Act, the desirability of a nationally uniform trademark law, and the extent to which state anti-dilution statutes enlarge trademark rights. See Gilson, 1 Trademark Protection and Practice at $\$ 8.01$ (3) (cited in note 78).

${ }^{83}$ U.S. Jaycees, 661 F.Supp. at 1367-68. See also Handler, 75 Trade-Mark Rptr. at 28587 (cited in note 81) (noting that "the piecemeal approach to trademark regulation" created by the anti-dilution statutes is inconsistent with the Lanham Act's purposes).

94 See McCarthy, 1 Trademarks and Unfair Competition at 140 (cited in note 19). 
people argue that regulation of unfair competition traditionally has been left to the states and that usurpation of state regulatory power would merely add more confusion to an already muddy area of the law. This section of the comment examines the degree to which federal law currently regulates unfair competition, at least outside the Second Circuit. To the extent that federal law already governs unfair competition claims and to the extent that courts accepting Lanham Act preemption would continue to apply the same federal unfair competition principles as they have in the past, preemption of state law by the Lanham Act would not work a radical change in substantive law. The primary effect of preemption would be to eliminate the troublesome constitutional problems that arise when federal courts apply state law to multistate disputes. Recourse to preemption analysis would also increase judicial honesty since courts would be more open about the present practice of applying federal precedent to unfair competition claims.

1. Reliance on Long-Standing Federal Precedent. Before Erie, "a vast body of federal precedents had established a rather effective set of rules against unfair business conduct." those decisions technically lost their precedential value. However, because state law was so underdeveloped, federal courts often resorted to their own precedent anyway. ${ }^{96}$ This practice continues today: the courts routinely decide unfair competition cases based on prior federal decisions. Capital Films Corp. v. Charles Fries Productions is a good example. ${ }^{97}$ In trying to decide whether a claim of "reverse confusion" 98 was actionable at common law, the court followed another federal district court decision, which in turn was based solely on federal precedent. The Capital Films court recognized that Texas law controlled, but because no applicable precedent could be found, the court felt the only homage it needed to

9s Derenberg, 32 N.Y.U.L.Rev. at 1030 (cited in note 87).

96 See, e.g., Capital Films Corp. v. Charles Fries Productions, 628 F.2d 387, 393-94 (5th Cir. 1980); Bass Buster, Inc. v. Gapen Mfg. Co., Inc., 420 F.Supp. 144, 156 (W.D.Mo. 1976). See also Note, Effect of Erie $v$. Tompkins on Unfair Competition Actions in Federal Courts, 16 J.B.A.Kan. 225, 228 (1947).

${ }^{97} 628$ F.2d 387 (5th Cir. 1980).

98 Reverse confusion describes a situation where customers misperceive the junior user of a trademark to be the original and authentic source of the goods. The senior user is then perceived to be the infringer when in fact it is the one suffering from the infringement. Since such confusion may actually benefit the senior user, there is a split of authority as to whether it is actionable. Compare Westward Coach Manufacturing Co. v. Ford Motor Co., 388 F.2d 627, 633-34 (7th Cir. 1968) (reverse confusion not actionable under Indiana law), with Big O Tire Dealers v. Goodyear Tire \& Rubber Co., 561 F.2d 1365, 1371-72 (10th Cir. 1977) (reverse confusion actionable under Colorado law). 
pay the state was to ensure that its finding was not actively repugnant to Texas state law. ${ }^{99}$ As Capital Films demonstrates, federal decisions have continued to hold sway in the absence of strong state precedent, although no court has been willing to hold outright that federal common law governs most unfair competition claims. ${ }^{100}$

Even when a federal court does examine state law, the result is usually a finding that because the state does not have "a well developed body of trademark caselaw, fundamental trademark principles will be applied to the common law claims." mental principles" pervade the adjudication of unfair competition claims. Only the Second Circuit follows state law on a regular basis. ${ }^{102}$

Strictly speaking, it might be a misnomer to label a decision an application of federal common law when the court declares that it is only using federal precedent to fill a gap in state law. Nominally, the court is applying state law, but substantively it is using either a restatement of pre-Erie federal law or a logical development therefrom uninfluenced by any state court or legislature. These cases are not examples of courts openly preferring a federal law which conflicts with state law. Rather, they are examples of how federal precedent and principles continue to thrive.

2. Reliance on Official Trade Board Decisions. Federal common law in the field of trademark and product configuration rights also derives from the decisions of the Trademark Trial and Appeal Board (TTAB) and cases appealed therefrom to the Federal Circuit and its predecessor, the Court of Customs and Patent Appeals. The Board's primary function is to determine whether trademarks are registrable and to conduct opposition and cancellation proceedings by which interested parties can dispute the claims of appli-

99 628 F.2d at $393-94$.

${ }^{100}$ For examples of judicial reticence in admitting the application of federal common law, see W.T. Rogers Co., Inc. v. Keene, 778 F.2d 334, 338 (7th Cir. 1985); Capital Films, 628 F.2d at 394 n.4, Keebler Co. v. Rovira Biscuit Corp., 624 F.2d 366, 372 (1st Cir. 1980). All of these courts recognized that state law might apply, but they nevertheless employed federal precedent either because the parties did not argue state law, because no state precedent was on point, or because state and federal law were similar.

${ }^{101}$ Bass Buster, 420 F.Supp. at 156.

102 However, even some Second Circuit panels will resort to a silent application of federal common law. See, e.g., Plus Products v. Plus Discount Foods, Inc., 722 F.2d 999, 1003-5 (2d Cir. 1983); C.L.A.S.S. Promotions v. D.S. Magazines, Inc., 753 F.2d 14, 17 (2d Cir. 1985). Both opinions cite federal precedent almost exclusively and give no indication that they are applying state law. 
cants and registrants. ${ }^{103}$ The Board will grant registration to users of inherently distinctive marks or users of descriptive marks which have become distinctive through commerce-that is, weak marks that have acquired secondary meaning. ${ }^{104}$ Registration will not be granted if a likelihood of confusion exists between the mark in question and any other mark previously used in commerce. ${ }^{105}$

In making determinations regarding such issues as confusion and functionality, the Board and courts deciding appeals therefrom have generated a considerable body of case law directly applicable to the adjudication of typical unfair competition claims. ${ }^{106}$ As a result, other courts frequently cite Federal Circuit and TTAB opinions when looking for guidance on these issues. ${ }^{107}$

3. Reliance on $\S 43(a)$ of the Lanham Act. The greatest source of federal common interpretive law has been $\S 43(\mathrm{a})$ of the Lanham Act. ${ }^{108}$ As mentioned earlier, the courts early on refused to recognize $\S 44(\mathrm{~h})$ and $\S 44(\mathrm{i})$ as establishing a federal law of unfair competition. Later courts wishing to establish federal common law in this field had to rely on $\S 43(\mathrm{a})$, the provision creating a federal cause of action for false descriptions or representations of goods. Although this provision was originally construed quite narrowly, its scope has been expanded to cover many areas of unfair competition. ${ }^{100}$ None of the cases extending the literal wording of $\S$ 43(a) admit to the creation of federal common law, yet many courts have relied on this section to promulgate broad principles of unfair competition law. ${ }^{110}$ Regardless of the courts' hesitance to declare outright that federal law applies to multistate unfair competi-

10315 U.S.C. $\S \S 1051,1063-64$ (1982 \& Supp. 1985).

10415 U.S.C. $\S 1052$.

105 Id.

${ }^{106}$ See, e.g., In re Bose Corp., 772 F.2d 866 (Fed.Cir. 1985) (deciding a functionality standard); In re Great Lakes Canning, Inc., 227 U.S.P.Q. 483 (T.T.A.B. 1985) (likelihood of confusion standard).

${ }^{207}$ See, e.g., Sno-Wizard Mfg., Inc. v. Eisemann Products Co., 791 F.2d 423, 426 n.3, 427 n.4 (5th Cir. 1986); W.T. Rogers Co., Inc. v. Keene, 778 F.2d 334, 339-40, 342, 345 (7th Cir. 1985); Sicilia Di R. Biebow \& Co. v. Cox, 732 F.2d 417, 427-8 (5th Cir. 1984).

${ }_{108} 15$ U.S.C. $\$ 1125$ (a) (1982). For partial text, see note 89.

109 For a history of judicial interpretation of $\S 43(\mathrm{a})$, see Bauer, 31 U.C.L.A.L.Rev. at 681-695 (cited in note 87); Gilson, 1 Trademark Protection and Practice at $\$ 7.02$ (cited in note 78 ).

${ }^{110}$ Many commentators have hoped that the expansion of $\S 43(a)$ will eventually result in a comprehensive law of unfair competition. See Bauer, 31 U.C.L.A.L.Rev. 671,672 (cited in note 87); Derenberg, 32 N.Y.U.L.Rev. 1029, 1031-32 (1957) (cited in note 87). Judges have also encouraged such growth. See Maternally Yours v. Your Maternity Shop, 234 F.2d 538, 546 (2d Cir. 1956) (Clark concurring) (declaring that "broad and liberal construction" of "this remedial legislation [\$ 43(a)]" is proper; "[i]ndeed, there is indication here and elsewhere that the bar has not yet realized the potential impact of this statutory provision.") 
tion claims, judges have developed a substantial body of case law that remains the major source of precedent used by the courts today.

Conclusion

This comment has outlined several problems caused by the adjudication of multistate unfair competition claims under state law. Lanham Act preemption of extra-territorial applications of state law provides the simplest, most practical solution. It would alleviate constitutional concerns and simplify difficult choice of law decisions. Judges are faced with important constitutional questions when they decide what law to apply to a multistate unfair competition claim. Rather than facing the difficult task of sorting contacts and policies under the application of state law, courts should be able to look to the Lanham Act and decide the case under federal law. Because courts are already applying federal principles in multistate unfair competition actions, Lanham Act preemption would cause no great departure from the status quo. However, even if the preemption argument is ultimately rejected, future unfair competition decisions must be adjudicated in a different manner if they are to be responsive to the commerce, due process, and full faith and credit clauses. 